energy intake was reduced by only $2.6 \%$. moments in a sleeping house the isolation Cutting out the carbohydrates led to a distinct increase in protein and fat consumption. On the alternative regimen mean daily calorie intake was reduced from 1,800 to about $1,200 \mathrm{kcal} /$ day, a reduction of $30 \%$. Mean weight losses after six weeks were $1.0 \mathrm{~kg}$ and $3.1 \mathrm{~kg}$ respectively. On the standard calorie-restricting diet serum cholesterol fell initially from $215 \mathrm{mg} / 100 \mathrm{ml}$ to $198 \mathrm{mg} / 100 \mathrm{ml}$ and then returned to the original level. On the low-carbohydrate diet the mean serum cholesterol level rose from $208 \mathrm{mg} / 100 \mathrm{ml}$ to $236 \mathrm{mg} / 100 \mathrm{ml}$ and in a few individuals to levels above $300 \mathrm{mg} / 100$ $\mathrm{ml}$. In general, the volunteers found that keeping to the low-carbohydrate diet was more difficult than keeping to the calorierestricting one, and the former regimen was estimated to be more expensive.

A critique of low-carbohydrate ketogenic weight reduction regimens has been published by the American Medical Association Council on Foods and Nutrition. ${ }^{2}$ I should regard two of the summary points as being most relevant:

"(3) The Council is deeply concerned about any diet that advocates an 'unlimited' intake of saturated fats and cholesterol-rich foods. In persons who respond to such a diet with an elevation of plasma lipids and an exaggerated alimentary hyperlipemia, the risk of coronary artery disease and other clinical manifestations or atherosclerosis may well be increased-particularly if the diet is maintained over a prolonged period.

“(4) Any grossly unbalanced diet, particularly one which interdicts the $45 \%$ of calories that is usually consumed as carbohydrates, is likely to induce some anorexia and weight reduction if the subject is willing to persevere in following such a bizarre regimen. However, it is unlikely that such a diet can provide a practicable basis for long-term weight reduction or maintenance, that is, a lifetime change in eating and exercise habits."

While a low-carbohydrate diet may be more acceptable to certain patients, such a diet will cause elevation of blood cholesterol in some people. If one is worried about cholesterol levels when planning a diet, it is prudent to limit foods high in cholesterol and saturated fat. Such a diet will still contain adequate amounts of fat-soluble vitamins. -I am, etc.,

J. I. MANN

Department of the Regius Professor of Medicine, Radcliffe Infirmary,

Oxford

1 Kouwenhovew, T., and Drijver, A., Voeding, 1973,

34. 180.
of the American Medical Association, 1973, 224, of the American Medical Association, 1973, 224, $180,285,1231,1415$.

\section{Cancer and the Patient}

SIR,-Professor G. W. Milton (27 October, p. 221) displays great understanding of the patient's reaction to a diagnosis of cancer. He also makes a point of enormous practical importance. In Britain we tend to examine the patient and then offer to see the accompanying relative, often not in the patient's presence. Frightened patients are thus effectively isolated from their most valuable source of support. At the back of their mind they may never quite believe that husband or wife has been entirely honest and is not concealing further bad news in an attempt to spare the patient greater distress. The loved one joins, as it were, life's conspiracy against the patient. In their darkest must be unbearable. But if the doctor discusses the situation with all concerned there can be no grounds for mistrust. Though this can be much more difficult, it is more humane.-I am, etc.,

Hammersmith Hospital,

\section{E. A. Macdonald} London $\mathbf{W} .12$

\section{F.D.P. Levels in Intravascular Haemolysis}

SIR,-Dr. S. D. Slater and his colleagues (1 September, p. 471) suggest that chronic haemolysis does not lead to intravascular coagulation in the absence of "other precipitating factors." This is true also in clinical cases of acute massive haemolysis, as shown by the normal levels of serum fibrinogen - fibrin degradation products (F.D.P.) and the absence of other signs of intravascular coagulation in sensitive Sardinian subjects following ingestion of fava beans. ${ }^{1}$ On the other hand, situations of acute haemolysis of comparable degree, such as the transfusion of incompatible blood, drowning haemoglobinaemia, and ingestion of strong acids, ${ }^{3}$ are accompanied by consumption of coagulation factors and increased F.D.P. levels. What, then, are the "precipitating factors" and why does intravascular coagulation occur in some cases and not in others?

Dr. E. N. Wardle (13 October, p. 111) is right in emphasizing the key role played by the state of functional activity of the reticuloendothelial system. This has been convincingly demonstrated by the experimental findings of Rabiner and Friedman, who showed that intravascular coagulation followed the infusion of lysed red cells only after depression of the reticuloendothelial system by carbon or splenectomy. Therefore I think that the different findings in the acute attack of favism and in incompatible blood transfusion may be similarly explained by the presence of an intact reticuloendothelial system in the former and by its depression by shock in the latter. ${ }^{6}$

I cannot support the suggestion of $\mathrm{Dr}$. Wardle that impaired removal of fibrin by defective fibrinolysis plays a relevant role in conditioning the occurrence of intravascular coagulation after haemolytic anaemia. In unpublished observations on cases of favism the fibrinolytic activity was very depressed and yet there was no evidence of fibrin deposition and intravascular coagulation.-I am, etc.,

\section{P. M. MANNUCCI}

Haemophilia and Thrombosis Centre,

University of Milan,

Italy

Mannucci, P. M., Lobina, G. F., Caocci, L., and Dioguardi, N., Blood, 1969, 33, 207

Sack, E. S., and Nefa, O. M., Transfusion, 1970, 10. 317 .

Riedler, G., Frick. P. G., and Straub, P. W Helvetica., Medica Acta, 1968, 34, 205.

4 Riedler, G., Straub, P. W., and Frick, P. G. Helvetica Medica Acta, 1968, 34, 223.

5 Rabiner, S. F., and Friedman, L. H., British Fournal of Haematology, 1968, 14, 105.

Hardway, R. M., et al., fournal of Trauma, 1964, 4,624 .

\section{Muscle Cramps during Maintenance Haemodialysis}

SIR,-May we have the privilege of replying briefly to the letter from Dr. G. R. D. Catto and others (3 November, p. 301)?
With regard to their first point, we must disclaim any intention of suggesting that the mean inter-dialysis weight gain of 4-5 kg during isonatric dialysis (dialysate sodium = $145 \mathrm{mmol} / \mathrm{l}$.) was due mainly to the threeday interval between twice-weekly dialyses. On the basis of twice-weekly dialysis, the inter-dialysis weight gain almost doubles on isonatric dialysis compared with lowsodium dialysis. ${ }^{1}$ However, it is obvious that if our patients were receiving thrice-weekly dialysis the mean inter-dialysis weight gain would be less. Our range of weight change would, we agree, be unacceptable on low-sodium dialysis, but a much wider range of weight fluctuation is acceptable during isonatric dialysis. Our patients are advised to limit their weight gain to a maximum of $1 \mathrm{~kg}$ per day between dialyses. We reiterate that all the patients in Dundee, including those on home dialysis, tolerate well both their weight gain and the increased ultrafiltration required to maintain their ideal postdialysis weight. Indeed, those who remember pre-isonatric days react with dismay to any suggestion that they return to low-sodium dialysis with its attendant symptoms of "disequilibrium."

In fact, we have never advocated the use of isonatric dialysate for the sole and specific purpose of reducing cramps. The decrease in the incidence of cramps was one incidental benefit among others. ${ }^{2}$ Port et al. ${ }^{3}$ have independently demonstrated the benefit of "high-sodium" dialysate (149 $\mathrm{mmol} / \mathrm{l}$.) in reducing symptoms of disequilibrium and maintaining a more normal electroencephalographic pattern during an experimental single dialysis.

We should perhaps mention that some insight and acquired skill are required in regulating the increased rate of ultrafiltration for some patients. However, once established, the routine has proved entirely satisfactory, and isonatric dialysis has remained standard practice for all patients in Dundee, including those on home dialysis, over the past three years.-We are, etc.

W. K. STEWART LAURA W. FLEMING

Department of Medicine,

University of Dundee,

Dundee 1 Stewart, W. K., Fleming, L. W., and Manuel,
M. A., Proceedings of the European Dialysis and
Transplant Association, 1972, , 111.
2 Stewart, W. K., Fleming, L. W., and Manuel,
M. A., Lancet, 1972, 1. 1049.
3 Port, F. K., Johnson, W J., and Klass, D. W.,
Kidney International, 1973, 3, 327.

\section{Aid to Lumbar Puncture}

SIR,-In performing lumbar puncture it is advisable to use as fine a needle as possible. There are now a number of manufacturers who produce a 22-gauge disposable spinal needle. With such a fine needle there are problems both in introducing the needle through the skin and ligaments and in ensuring that the needle travels in the desired direction. There are numerous ways of overcoming these problems and the purpose of this letter is to describe an easy and convenient way of dealing with both introduction and direction of the spinal needle.

After the usual preparation an intravenous cannula of an appropriate size (I use a no. 1 Braunula) is inserted in the selected spinal interspace until it is well placed in the ligaments. The inner needle portion is with- 